\title{
ANALYSIS OF FACTORS INFLUENCES THE PERFORMANCE AND THE COST OF BASIS OF CONSIDERATION DECISION-MAKING SYSTEM DIRECT APPOINTMENT IN THE CONTRACT OF FIXED UNIT RATE
}

\author{
Agus Suroso Kristanto, Erry Rimawan \\ Program Studi Teknik Sipil - Universitas Mercubuana \\ kristanto.mbu@gmail.com
}

\begin{abstract}
In business activities construction services the interior of today , users variatif use the kind of the kind contract construction. This they do in addition to reduce the cost of the production of ( implementation costs project ), also was to make procurement processes in internal. One of a contract that often worn is the contract fix unit rate .In the system this contract, contractors experienced difficulties even loss.As for this study aims to find variable influence contract system fixed unit rate to swelling the cost of rap and swelling time, determines the dependent variable the most dominant and at the very least dominant that influence the swelling the cost and the time.

This research writer use is a method of observation ( direct observation ) and quantitative methods namely the data collected from project rate fixed unit for 8 months, from january until september 2016 .The primary data obtained from implementing contractor namely PT. Adimas Pandu Serasi and specialist subkontraktor of the projects being researched .Data collection is done by spreading the questionnaire to the contractor and subkontraktor implementers specialist who handle the project .Data analyzed by correlation pearson , a method of linear regression worship of idols, and a test of that hypothesis ( test and test $t \mathrm{f}$ ) and adjusted test $r$ square .Secondary data taken from the principal contractor in the form of budget plan fees ( RAB ), shopdrawing that has been approved.

The results of the study obtained factors the most dominant in swelling the charge on a contract this is on the project high building ( high rise building ) are often material have to follow the rule building so material have been bought will be brought back into supplier with compensation , and factors that at least dominant are there are many price unit in this contract lower than the price actually . While factors the most dominant impact on swelling time is the jobs added less whose value did not too large not given the addition of time, and factors that at least dominant are schedule for implementing this job long because the administrative process of contract system was long .
\end{abstract}

Key words: Fixed unit rate, Lumpsum, Cause, Impact, Influence

\section{INTRODUCTION}

Fixed Unit Rate contract system is a mutual agreement between several service providers and service users to use unit price of all work items on all projects that run within a certain time according to the agreement. In this case, the Fix Unit Rate contract which is followed by PT. Adimas Pandu Serasi is a contract at PT. Bank Permata. Contract Fixed Unit Rate PT. Bank Permata followed by PT. Adimas Pandu Serasi is a package of interior, civil, furniture and mechanical electrical, has been going on since 2012 with price review and renewal of contract once a year. In its implementation, PT. Adimas Pandu Serasi in Permata Bank's Fixed Unit Rate project is experiencing difficulties and not all Fixed Unit Rate projects generate sufficient profits, many of which cost much more than the Implementation Budget Plan (RAP). Therefore, the authors feel the need to examine the issue in order to be the basis of consideration to determine the steps - effective and efficient steps to run projects with this fixed unit rate contract system.

Of the five projects undertaken during the period of January - June 2016, the execution cost exceeds that of RAP and its implementation time has been delayed. Larger implementation costs of RAP and delays in the Permata Bank Permit Fixed Unit Rate project are due to several factors, including the price of overwork items, sudden design changes, tight work schedules that require more labor costs, night resulting in swelling of overtime costs, prices of fluctuating goods in the market, inflation and so on. The author will try to examine the problem by using primary data, that is by distributing questionnaires to the respondents related to the project and 
using secondary data that is by taking the project data that has been done for eight months, which can be RAB data, project schedule, variation order, also project profit data.

The project value on the fixed unit rate contract is actually not very large, but the number of projects in one year makes it worth considering to follow. For that, in this study the authors want to discuss the swelling of the implementation fee on each project bank Permata for eight months. The author hopes that this research can be useful both in terms of theoretical that can give a contribution in enriching the insight about fixed unit rate contracts, and useful from a practical point of view that can be taken into consideration by the determinant of contractor policy towards the decision of participation in Fixed Unit Rated contract elsewhere, and can also be used as a comparison against projects with similar contracts.

\subsection{Formulation of the problem}

Based on the above description of the background, then the following problem formulation that must be answered in this study:

- How many factors lead to swelling of implementation costs on Bank Permata fixed rate rate projects?

- How much contribution each factor contributes to the swelling of implementation costs in the projects?

- Which factors are most dominant causing swelling of implementation costs on those projects?

- Which factors are the least dominant causing swelling of implementation costs on those projects?

\subsection{Research purposes}

The purpose of this research are:

- Gain factors - factors that cause the cost swelling of the implementation of the project Bank Permata Fixed Unit Rate

- Gain data the magnitude of the contribution of each factor causing the cost swelling implementation

- Getting the most dominant factor data causing swelling of implementation costs on those projects

- Obtain the least dominant factor data that causes swelling of implementation costs on the projects

\subsection{Scope of problem}

Given the limited research time and with the aim that this research is directed to the established objectives, the limitations of the problem in this subject are as follows:

- The data of the fixed unit rated project of Permata bank is taken from PT. Adimas Pandu Serasi

- Based on interviews and data obtained from project managers

- The research is intended to find out the main factors causing swelling of implementation costs.

\section{LITERATURE REVIEW}

In the contract there are various types of contract where the type of contract used is viewed from several aspects, among others, based on the form of reward, based on the period of implementation and based on the user of goods / services (Article 30 of Presidential Decree Number 80 Year 2003).

The types of contract according to Article 30 Presidential Decree Number 80 Year 2003, among others:

1. Based on Forms of Rewards:

- A Lump sum contract is a procurement contract for the completion of all work within a certain time limit, at a fixed and fixed price, and all risks that may occur in the completion of the work are fully borne by the provider of goods / services.

- Unit price contract is a procurement contract for the completion of all work within a specified time limit, based on fixed and fixed unit prices for each unit / job item with certain technical specifications, whose work volume is temporary, while the payment is based on the results measurement of the volume of work actually performed by the provider of goods / services.

- The combined contract of Lump sum and Unit price is a contract which is a combination of Lump sum and Unit price in a contracted work. This is the type of contract used by Bank Permata.

- The contract of receipt is the contract of procurement of goods / services for the completion of all work within a certain time limit with a fixed and fixed price until all the buildings / construction, equipment and main or supporting network can function properly in accordance with the predefined criteria.

- A percentage contract is a contract for the execution of a consultancy service in the field of construction or certain contracting work, whereby the consultant receives the service fee based on a certain percentage of the value of the physical construction / charter work.

2. Based on the Implementation Period:

- Single-year contract is a contract of work execution that binds budget funds for a period of 1 (one) budget year.

- Multi-year contract is a contract of work execution that binds budget funds for a period of more than 1 (one) budget year which is done upon approval by the finance minister for procurement financed by 
APBN, Governor for procurement financed by provincial APBD, Regent / Mayor for procurement financed by APBD Regency / City.

3. By Number of Users Goods / services:

- A single procurement contract is a contract between a work unit or a project with a particular goods / service provider to complete a particular job within a specified time.

- A joint procurement contract is a contract between several work units or multiple projects with certain goods / service providers to complete certain work within a certain time according to the clear joint activities of each work unit and joint funding as outlined in the collective agreement.

\section{RESEARCH METHODOLOGY}

The collection of data for this research is taken from the primary and secondary data, where the data will be sorted, for other data obtained from various reference books, as well as scientific journals on Variation Order / Change Order, and on project evaluation.

\section{A. Primary Data}

Primary data obtained from the data collection that is with the questionnaire of the project under study as well as some projects as research respondents are project implementers. In this study the intent and purpose of using primary data is to measure the quantitative or statistical level and the results of questionnaires from respondents who completed pertayaaan variables to respondents about the difficulties of fixed-rate project Bank Permata.

\section{B. Secondary Data}

The collection and collecting of secondary data concerning Permata Bank fixed rate project project are:

1. Project schedule

2. Document of the Budget Plan Plan

3. Project profit data

4. Image work etc.

After the collection of primary and secondary data, the authors analyzed the data collection processed and identified for Permata fixed unit rate contract research, the research data was processed using Statistical Package for Social Science (SPSS) and Microsoft Excel program in making tables and graphs easier and simple in processing and reading.

Processing analysis and identification include:

1. Measurement of validity and reliability of the questionnaire

2. Analysis of determinant variables

3. Multiple linear regression analysis

4. Test the hypothesis

5. Partsial test $\mathrm{t}$

6. Simultaneous Test $\mathrm{f}$

7. Adjusted Test R

\section{DATA ANALYSIS AND DISCUSSION}

In this study, the authors used a questionnaire with 30 respondents with 36 sub-variables. Penilainnya using Likert scale with ladder arranged

- Strongly Disagree

- Less Agree

- Agree

- More than Agree

- Strongly agree

While penilainnya is from one to five, ranging from strongly disagree the value 1 and so on.

In the first questionnaire, the authors retrieve the statement variables from previous journals with the theme of CCO and project delay analysis, then the authors verify the variables to the five people who the authors deem most understand the problems of this contract system. The statements they deem irrelevant to the author of the elimination so that the remaining relevant statements are then authored to use for the second stage questionnaire.

In the second stage questionnaire, from the results of the data with the Statistical Package for Social Science (SPSS) program performed significant tests of correlation coefficient at a significant level of 0.05 or $5 \%$ significance. In a significant test done by comparing the value of rhitung> rtabel which is rhitung is 23 variables 
with 30 samples and rtabel $30=\mathrm{N}=0.361$ from significant rtabel 0.05 or $5 \%$ significant got the variables from the validity test that is 23 variables

1. Test Reliability and Validity

On validity test there are some sub variable which is not valid while in reliability test all answer from respondent is reliable or consistent.

2. Multiple Linear Regression Analysis

A. Influence Against Swelling Cost

\begin{tabular}{|l|c|c|c|c|}
\hline \multicolumn{4}{|c|}{ Model Summary $^{\mathbf{b}}$} \\
\hline Model & $\mathrm{R}$ & R Square & Adjusted R Square & Std. Error of the Estimate \\
\hline 1 & $.936^{\mathrm{a}}$ & .877 & .414 & 2.568 \\
\hline
\end{tabular}

Based on the above table obtained $\mathrm{R}$ number of 0.936 . This shows that there is a very strong relationship between X1.2, X2.1, X2.2, etc. against the cost swelling.

Based on the above table obtained the number R2 (R Square) of 0.877 or $87.7 \%$. This shows that the percentage of contribution of independent variables $(\mathrm{X} 1.2, \mathrm{X} 2.1, \ldots . \mathrm{Xn}$ ) to the dependent variable (swelling cost) of $87.7 \%$. Or variations of the independent variables used in the model (X1.2, X2.1, ... Xn) are able to explain $87.7 \%$ of the variation of the dependent variable (cost raiser). While the rest of $12.3 \%$ is influenced or explained by other variables that are not included in this research model.

\begin{tabular}{|c|c|c|c|c|c|c|}
\hline \multicolumn{7}{|c|}{ ANOVA $^{\mathrm{a}}$} \\
\hline \multicolumn{2}{|c|}{ Model } & Sum of Squares & $d f$ & Mean Square & $\mathrm{F}$ & Sig. \\
\hline \multirow[t]{3}{*}{1} & Regression & 187.375 & 15 & 12.492 & 1.894 & $.283^{b}$ \\
\hline & Residual & 26.375 & 4 & 6.594 & & \\
\hline & Total & 213.750 & 19 & & & \\
\hline \multicolumn{7}{|c|}{$\begin{array}{l}\text { a. Dependent Variable: Y } \\
\text { b. Predictors: (Constant), X12, X2.1, X4, X1.2, X8.2, X2.5, X9, X8.3, X2.3, X10.2, X2.4, X3.1, X2.2, } \\
\text { X6.2, X6.1 }\end{array}$} \\
\hline
\end{tabular}

F table of 2.203 can be searched in Ms Excel by means of empty cell type =finv $(0.05 ; 15 ; 20)$ then enter.

The value of $\mathrm{F}$ arithmetic $<\mathrm{F}$ table $(1.894<2.203)$, then Ho is accepted, meaning there is no significant influence between X1.2, X2.1, x2.2 ... .Xn together against against the cost swelling. So from this case it can be concluded that X1.2, X2.1, x2.2 ... .Xn together have no effect on the project cost swelling. 


\begin{tabular}{|c|c|c|c|c|c|c|}
\hline & & & Coefficients & & & \\
\hline & & Unstandardize & Coefficients & $\begin{array}{l}\text { Standardized } \\
\text { Coefficients }\end{array}$ & & \\
\hline Mo & & B & Std. Error & Beta & $\mathrm{t}$ & Sig. \\
\hline 1 & (Constant) & 8.954 & 14.085 & & .636 & .560 \\
\hline & $\mathrm{X} 1.2$ & -2.494 & 1.182 & -.596 & -2.110 & .103 \\
\hline & $\mathrm{X} 2.1$ & 3.068 & 1.383 & .733 & 2.218 & .091 \\
\hline & $X 2.2$ & -1.478 & 1.710 & -.525 & -.865 & .436 \\
\hline & $\mathrm{X} 2.3$ & .249 & 2.954 & .056 & .084 & .937 \\
\hline & $\times 2.4$ & -1.738 & 2.865 & -.408 & -.607 & .577 \\
\hline & $\mathrm{X} 2.5$ & -.246 & 1.111 & -.073 & -.221 & .836 \\
\hline & X3.1 & -.856 & 2.101 & -.232 & -.407 & .705 \\
\hline & $X 4$ & -2.742 & 2.176 & -.363 & -1.260 & .276 \\
\hline & $X 6.1$ & -.652 & 3.180 & -.181 & -.205 & .848 \\
\hline & $\mathrm{X} 6.2$ & .840 & 2.556 & .285 & .329 & .759 \\
\hline & $\mathrm{X} 8.2$ & -1.243 & 1.805 & -.249 & -.688 & .529 \\
\hline & $\mathrm{X} 8.3$ & 2.649 & 2.061 & .542 & 1.285 & .268 \\
\hline & $\times 9$ & .618 & 1.841 & .139 & .336 & .754 \\
\hline & X10.2 & 2.373 & 2.274 & .415 & 1.044 & .356 \\
\hline & $\mathrm{X} 12$ & .670 & 1.417 & .149 & .473 & .661 \\
\hline
\end{tabular}

t table of 2.086 can be searched in Ms Excel by means of empty cell type $=\operatorname{tinv}(0.05,20)$ then enter.

Test Result $\mathrm{t}$

$\mathrm{X} 1.2-2.110<-2.086$ Ho accepted, meaning that there is no significant partial influence between this variable with the cost swelling

X2.1 2.218> 2.086 Ho is rejected, meaning that there is a significant partial influence between this variable with the cost swelling

X2.2 -0.865> -2.086 Ho is rejected, meaning that there is partially significant influence between this variable with the cost swelling

X2.3 $0.084<2.086$ Ho accepted, meaning that there is no significant partial influence between this variable with the cost swelling

X2.4 -0.607> -2.086 Ho is rejected, meaning that there is partially significant influence between this variable with the cost swelling

X2.5 - $0.221>-2.086$ Ho is rejected, meaning that there is partially significant influence between this variable with the cost swelling

X3.1 -0.407> -2.086 Ho is rejected, meaning that there is a significant partial influence between this variable with the cost swelling

$\mathrm{X} 4-1.260>-2.086$ Ho is rejected, meaning that there is partially significant influence between this variable with the swelling cost

X6.1 -0.205> -2.086 Ho is rejected, meaning that there is a significant partial influence between this variable with the cost swelling

X6.2 $0.329<2.086$ Ho is accepted, meaning partially there is no significant influence between this variable with the cost swelling

X8.2 -0.688> -2.086 Ho is rejected, meaning that there is partially significant influence between this variable with the cost swelling 
X8.3 $1.285<2.086$ Ho is accepted, meaning that there is no significant partial influence between this variable and the cost swelling

X9 $0.336<2.086$ Ho accepted, meaning that there is no significant partial influence between this variable with the cost swelling

$\mathrm{X} 10.21 .044<2.086$ Ho is accepted, meaning that there is no significant partial influence between this variable and the cost swelling

$\mathrm{X} 120.473<2.086$ Ho is accepted, meaning partially there is no significant influence between this variable with the cost swelling.

Linear Graph

Normal P-P Plot of Regression Standardized Residual

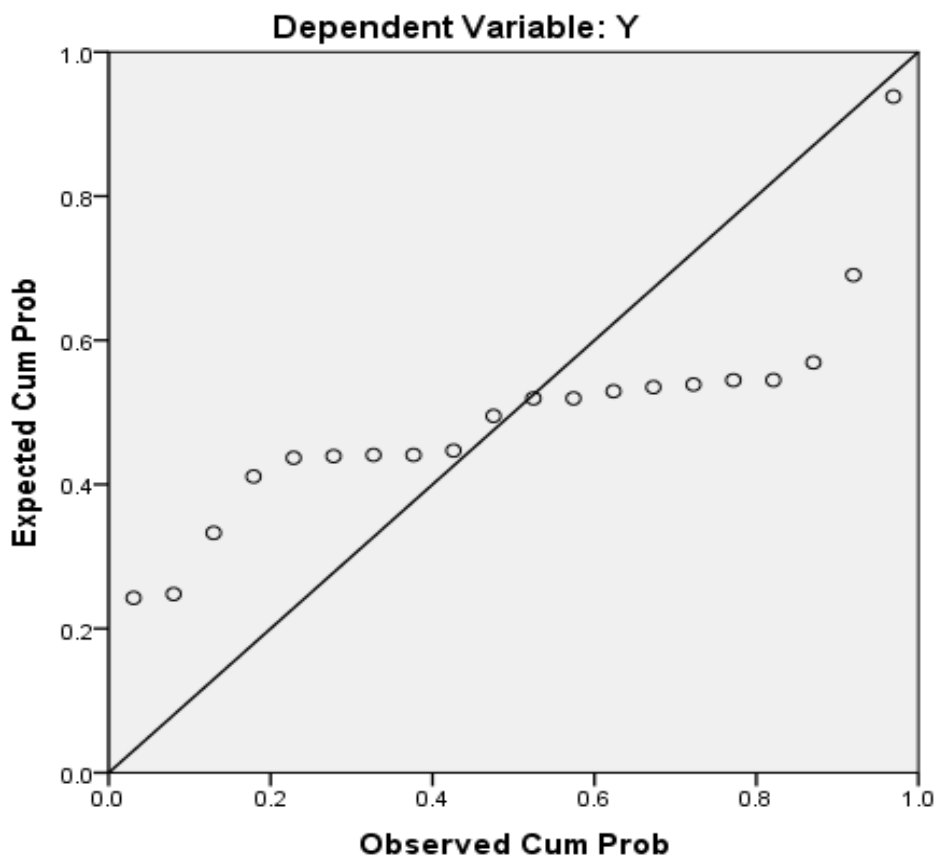

Conclusion

From the data above there are eight variables that are partially significant effect on cost swelling. Of the seven factors, the factors that have the most dominant influence are the variables X6.1 namely; on projects in high buildings, materials often have to be equated with building standards that result in brand changes, so items that have been ordered must be returned to the supplier with compensation. While the factors that influence the least dominant is the variable X2.1 namely; there are many items of work that the unit price in the fixed unit rate contract is lower than the actual price, this is detrimental to the contractor.

Factors that affect the cost swelling

- $\quad$ X2.1 => There are many items of work that unit price in the fixed unit rate contract is lower than the actual price, this is detrimental to the contractor

- $\quad \mathrm{X} 2.2=>$ There are many items of work that the unit price in the fixed unit rate contract is only the price of the goods alone, excluding tidal services, this is detrimental to the contractor

- $\quad$ X2.4 => There are some real price jobs that require an administrative fee that is not covered by the unit price in the contract

- $\mathrm{X} 2.5$ => Projects with fixed unit rate contract system The project budget plan is very tight, this makes the project can not be flexible, as in the project outside the city can not increase the number of workers when needed

- $\quad \mathrm{X} 3.1=>$ The tender process of fixed unit rate contract system is relatively short, so it is often miscalculated

- $\mathrm{X} 4$ => Documents of employment agreements between providers and service providers are not clear enough

- $\quad$ X6.1 => In high-rise projects, materials often have to be equated with building standards resulting in brand changes, so items that have been ordered must be returned to the supplier with compensation

- $\quad$ X8.2 => b. Often the contractor must succumb during the negotiation work added to the process quickly completed so immediately carried out in the field. 
B. Influence Against Time Swelling

\begin{tabular}{|l|c|c|c|c|}
\hline \multicolumn{4}{|c|}{ Model Summary $^{\mathbf{6}}$} \\
\hline Model & $\mathrm{R}$ & R Square & Adjusted R Square & Std. Error of the Estimate \\
\hline 1 & $.859^{\mathrm{a}}$ & .738 & .378 & 2.591 \\
\hline
\end{tabular}

Based on the above table obtained $\mathrm{R}$ number of 0.859 . This shows that there is a very strong relationship between X1.1, X1.2, X2.1, etc. against time swelling.

Based on the above table obtained the number R2 (R Square) of 0.738 or $73.8 \%$. This shows that the percentage of contribution of independent variables $(\mathrm{X} 1.1, \mathrm{X} 1.2, \ldots . \mathrm{Xn}$ ) to the dependent variable (swelling time) is 73.8\%. Or variations of the independent variables used in the model (X1.1, X1.2, ... Xn) can account for $73.8 \%$ of the variation of the dependent variable (cost buffer). While the rest of $26.2 \%$ influenced or explained by other variables that are not included in this research model.

\begin{tabular}{|c|c|c|c|c|c|c|}
\hline \multicolumn{7}{|c|}{ ANOVA $^{a}$} \\
\hline \multicolumn{2}{|c|}{ Model } & Sum of Squares & $\mathrm{df}$ & Mean Square & $\mathrm{F}$ & Sig. \\
\hline \multirow[t]{3}{*}{1} & Regression & 151.301 & 11 & 13.755 & 2.049 & $.159^{\mathrm{b}}$ \\
\hline & Residual & 53.699 & 8 & 6.712 & & \\
\hline & Total & 205.000 & 19 & & & \\
\hline \multicolumn{7}{|c|}{ a. Dependent Variable: Y } \\
\hline \multicolumn{7}{|c|}{ b. Predictors: (Constant), X9, X1.1, X6, X2.2, X3.2, X2.1, X1.2, X7, X8, X4, X3.1 } \\
\hline
\end{tabular}

F table of 2.309 can be searched in Ms Excel by means of empty cell type $=$ finv $(0.05 ; 11 ; 20)$ then enter.

$\mathrm{F}$ arithmetic $<\mathrm{F}$ table $(2.049<2.309)$, then Ho is accepted, meaning there is no significant influence between $\mathrm{X} 1.1, \mathrm{X} 1.2, \mathrm{x} 2.1 \ldots . \mathrm{Xn}$ together against against time swelling. So from this case it can be concluded that X1.1, $\mathrm{X} 1.2, \mathrm{x} 2.1$... .Xn together have no effect on the swelling of the project time. 


\begin{tabular}{|c|c|c|c|c|c|c|}
\hline & & & Coefficients & & & \\
\hline & & Unstandardizec & Coefficients & $\begin{array}{l}\text { Standardized } \\
\text { Coefficients }\end{array}$ & & \\
\hline Model & & $\mathrm{B}$ & Std. Error & Beta & $\mathrm{t}$ & Sig. \\
\hline 1 & (Constant) & 33.135 & 18.915 & & 1.752 & .118 \\
\hline & $\mathrm{X} 1.1$ & 1.635 & 1.515 & .343 & 1.079 & .312 \\
\hline & $\mathrm{X} 1.2$ & -.612 & 1.496 & -.125 & -.409 & .693 \\
\hline & $\times 2.1$ & 2.623 & 1.114 & 1.033 & 2.355 & .046 \\
\hline & $\mathrm{X} 2.2$ & .923 & 2.467 & .165 & .374 & .718 \\
\hline & X3.1 & -2.506 & 2.215 & -.650 & -1.131 & .291 \\
\hline & $\times 3.2$ & -3.616 & 1.506 & -.909 & -2.401 & .043 \\
\hline & $X 4$ & -3.999 & 2.006 & -1.089 & -1.994 & .081 \\
\hline & $x 6$ & 1.222 & 1.300 & .225 & .939 & .375 \\
\hline & $\mathrm{X} 7$ & -.893 & 1.750 & -.209 & -.511 & .623 \\
\hline & $x_{8}$ & 2.803 & 2.726. & .545 & 1.028 & .334 \\
\hline & $x 9$ & -5.225 & 5.398 & -.875 & -.968 & .361 \\
\hline
\end{tabular}

Test Result t

X1.1 $1.079<2.086$ Ho accepted, meaning that there is no significant partial influence between these variables with time swelling

$\mathrm{X} 1.2-0.409>-2.086 \mathrm{Ho}$ is rejected, meaning that there is partially significant influence between this variable with time swelling

$\mathrm{X} 2.12 .355>2.086$ Ho is rejected, meaning that there is partially significant influence between this variable with time swelling

$\mathrm{X} 2.20 .374<2.086 \mathrm{Ho}$ is accepted, meaning partially there is no significant influence between this variable with time swelling

X3.1 -1.131> -2.086 Ho is rejected, meaning that there is partially significant influence between this variable with time swelling

X3.2 -2.401> -2.086 Ho is rejected, meaning that there is partially significant influence between this variable with time swelling

$\mathrm{X} 4-1.994>-2.086$ Ho is rejected, meaning that there is partially significant influence between this variable with time swelling

X6 $0.939<2.086$ Ho is accepted, meaning partially there is no significant influence between this variable with time swelling

$\mathrm{X} 7-0.511>-2.086 \mathrm{Ho}$ is rejected, meaning that there is partially significant influence between this variable with time swelling

X8 $1.028<2.086$ Ho accepted, meaning that there is no significant partial influence between these variables with time swelling

X9 $-0.968>-2.086$ Ho is rejected, meaning that there is partially significant influence between this variable with time swelling.Grafik Kelinieran 


\section{Normal P-P Plot of Regression Standardized Residual}

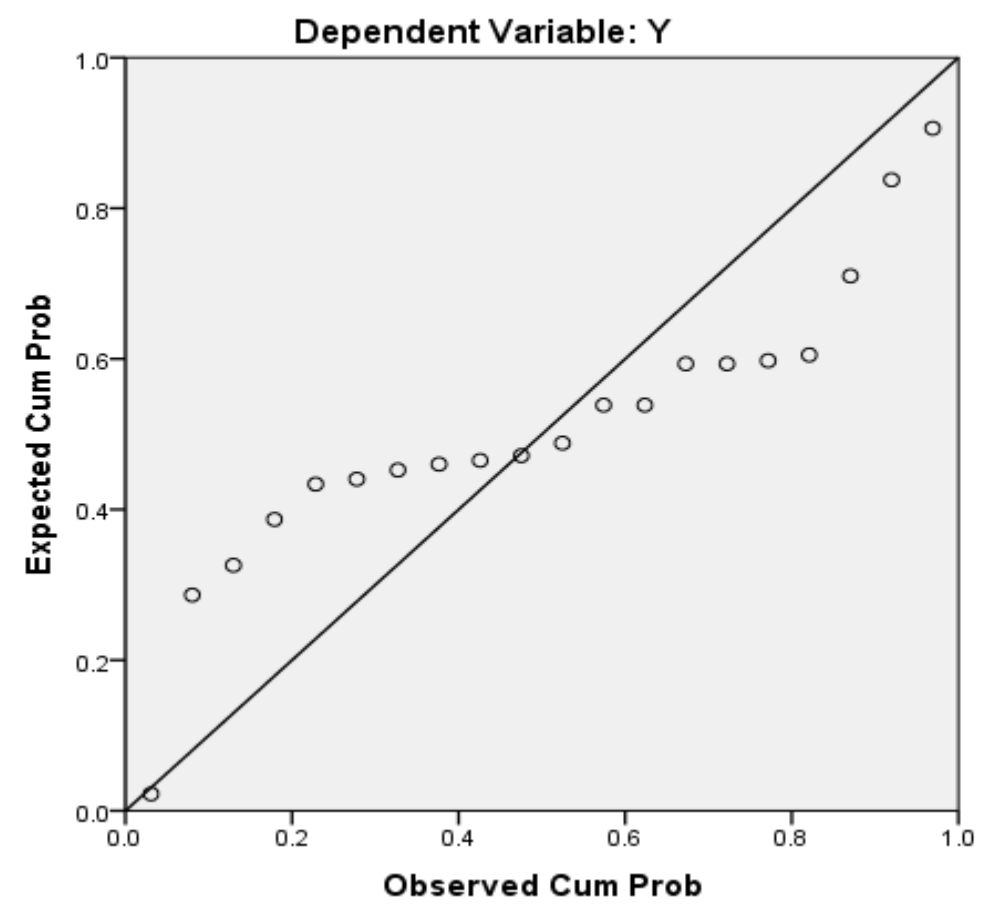

\section{Conclusion}

From the data above there are seven variables that are partially significant effect on cost swelling. Of the seven factors, the factors that have the most dominant influence are the variables X1.2 namely; if the value of variation order is not too large, the service provider is not given extra time.

While the factors that influence the least dominant is the variable X4 namely; the schedule of late implementation of the work because the system administration process of this contract long.

Factors influencing time swelling

- $\mathrm{X} 1.2=>$ Poses VO (added work) This contract system is taking too long to slow down the field work process

- $\quad$ X2.1 => In projects where part of the room is still operational, work which is at the beginning of the tender is scheduled to be done during the day on Monday to Sunday, in the execution turned into night because there are complaints from employees who work

- $\mathrm{X} 3.1=>$ The project licensing process is done in parallel, so that often the work related to the change appears to be dismissed by the licensee because it has not fulfilled the administrative requirements, this hampers the contractor's work

- $\mathrm{X} 3.2$ => A temporary work stop may occur due to pending approval of the design drawings of the design consultant of the structure designated by the service user

- $\mathrm{X} 4=>$ Schedule of implementation of the work is late because the system administration process of this contract long

- $\quad \mathrm{X} 7=>$ The service user is too long in the process of working schedule implementation

- $\mathrm{X} 9=>$ The project manager designated by the service user is less able to be co-ordinated so that it hinders the implementation process of the work.

\section{CONCLUDE AND ADVICE}

\section{Conclusion}

Based on the above preparations that have been done, can be taken conclusion:

1. The variables that have the most dominant effect on the swelling of implementation costs in the system of fixed unit rate contracts are; on projects in high buildings, materials often have to be equated with building standards that result in brand changes, so items that have been ordered must be returned to the supplier with compensation. While the least dominant influence is; there are many items of work that the unit price in the fixed unit rate contract is lower than the actual price, this is detrimental to the contractor. 
2. The most dominant variable affecting the swelling of execution time in this fixed unit rate contract system is; if the value of variation order is not too large, the service provider is not given extra time. The least dominant influencing factors are; the schedule of late implementation of the work because the system administration process of this contract long.

3. In linear test of multiple regression effect to cost, number $\mathrm{R} 2$ is $87.7 \%$, it means that variation of independent variable used in this model is able to explain equal to $87,7 \%$ variation of dependent variable (pembengkan fee). While the rest of $12.3 \%$ influenced or explained by other variables that are not included in this research model.

4. In linear test of multiple regression influence on time, the number R2 of $73.8 \%$, means that the variation of independent variables used in this model is able to explain $73.8 \%$ variation of the dependent variable (time pembengkan). While the rest of $12.3 \%$ influenced or explained by other variables that are not included in this research model.

5. In this multiple regression linear test, the author must eliminate the respondent whose answer is too far from the pattern of majority answers, to obtain a large enough R2. The answer is far from the pattern of answers majority of these authors suspect there is an indication less understood the problem on the statement they have to answer. PT. Adimas Pandu Serasi is a not very big company with 36 employees. In time-related issues, employees working in the back office lacked understanding so that they were impressed with the answer, and vice versa for cost issues, the field supervisor did not quite understand the problem.

\section{Suggestion}

From the above conclusions can be given suggestions that if useful both for contractors who follow a similar contract system and for further researchers:

1. In the project in high-rise building the Contractor should consider really because the chance of swelling is very high, if there are other options then this type of project should not be accepted

2. In the project where there are fewer and fewer added jobs, the field supervisor must take into account the additional time incurred due to this added work, and then addendum added time to the owner.

In this study obtained indications of differences in understanding between field personnel and personnel in the back office, this causes the emergence of indications of respondents' answers are relatively significant enough difference, therefore need to do further study that separates the group of respondents in the field and the group of respondents in back office. 